\title{
Refleksi diri melewati peristiwa retaknya keluarga dalam penulisan naratif: Studi analisis isi
}

\author{
Setiawati Intan Savitri, ${ }^{12}$, Bagus Takwin ${ }^{1}$, Amarina Ashar Ariyanto ${ }^{1} \&$ \\ Naimah Noviyanti ${ }^{2}$ \\ ${ }^{1}$ Fakultas Psikologi Universitas Indonesia,Depok \\ ${ }^{2}$ Fakultas Psikologi, Mercubuana Jakarta
}

\begin{abstract}
Abstrak
Saat individu berusaha mengatasi dampak emosional menghadapi keluarga retak, individu mencoba untuk melakukan refleksi atas peristiwa tersebut meski kadang sulit karena individu larut pada emosi negatif (ruminasi). Namun, individu juga mampu melihat pengalamannya secara adaptif dari perspektif pengamat dengan merespon tekanan dengan berjarak, sehingga mampu memaknai atau mendapatkan solusi dari tekanan. Penelitian ini bertujuan untuk menggambarkan proses refleksi diri adaptif ketika merespon peristiwa retaknya keluarga dengan cara menulis narasi dengan kata ganti personal satu (perspektif pelaku) dan menulis narasi dengan kata ganti personal nama-diri (perspektif pengamat). Riset Kross dkk. (2014) menyatakan bahwa kata ganti personal nama-diri merupakan metode untuk refleksi diri yang dianggap lebih adaptif dibandingkan dengan menggunakan kata ganti personal satu (perspektif diri pelaku) yang menyebabkan efek larut pada emosi negatif. Penelitian ini menggunakan pendekatan kualitatif dengan metode analisis isi. Subjek penelitian berjumlah tujuh orang ( 5 wanita dan 2 pria). Data diperoleh dari teks tulisan subjek yang mengikuti eksperimen menulis naratif selama empat hari berturut-turut. Hasil penelitian menunjukkan bahwa instruksi menulis dengan bahasa yang berjarak menggunakan perspektif pengamat, jika dibandingkan dengan instruksi menulis dengan menggunakan perspektif pelaku, pada level tertentu dapat membantu proses refleksi diri adaptif dengan mekanisme yang berbeda.
\end{abstract}

Kata kunci: analisis isi, refleksi diri adaptif, kualitatif, menulis naratif, keluarga retak

\begin{abstract}
When individuals try to work through the emotional impact of a broken home experience, it may not be successful because they experience rumination. However, there are also individuals who are able to see their experiences from different perspectives so they are able to do more adaptive selfreflection. This study aims to describe the process of adaptive self-reflection when responding to the events of broken home by narrative writing. We distinguished the two methods of writing: 1) using first personal pronoun (actor's perspective), and 2) using personal pronouns of own-name (observer perspective). Kross dkk (2014) stated that using own-name in writing are a more adaptive method for self-reflection compared to using first personal pronoun (actor's perspective) which may exert negative emotions. This study used a qualitative approach with the content analysis method. The research subjects were seven people ( 5 women and 2 men). Data were obtained from the text of the subject's writing which took part in an experiment of narrative writing for four consecutive days at one of the private universities in Jakarta. The results of the study showed that the instruction to write in a language that use an observer perspective, when compared to the writing instructions using actor perspective, at a certain level could help the process of adaptive self-reflection with a different mechanism.
\end{abstract}

Keywords: broken home, adaptive self-reflection, content analysis, narrative writing, qualitative

\section{Pendahuluan}

KPAI (Komisi Perlindungan Anak Indonesia) mencatat kasus anak korban perceraian tahun 2011 hingga 2016 di Indonesia menduduki peringkat kedua dengan jumlah kasus 4.294 (Nugraheny, 2016) Mengalami keluarga retak merupakan peristiwa yang cukup berat bagi anak-anak dan remaja, beberapa ahli mengategorikannya sebagai pengalaman yang menimbulkan tekanan berat ketiga setelah kematian orang tua dan kematian orang terdekat (Amato, 2000; Holmes \& Rahe, 1967). Kondisi tak terelakkan sebagaimana kondisi keluarga retak, adalah stimulus bagi individu yang mengalaminya, untuk melakukan refleksi diri. Refleksi diri mendorong seseorang untuk fokus pada diri, emosi negatif, serta persoalan yang 
dihadapinya. Refleksi diri ini dapat menghasilkan dua jenis dampak, yaitu dampak kondisi adaptif dan kondisi non-adaptif. Pada kondisi yang adaptif, seseorang akan mendapatkan insight, pemaknaan, solusi (Kross \& Ayduk, 2017; Kross \& Grossman, 2011).

Emosi negatif yang muncul pada anak yang mengalami keluarga retak berbeda dengan emosi negatif yang muncul pada anak yang mengalami peristiwa negatif lain. Sebab pada anak yang mengalami keluarga retak, emosi negatif yang muncul pada dasarnya bersifat tidak langsung, tidak seperti pada peristiwa konflik interpersonal (anak dengan orang tua, atau konflik anak dengan temannya) atau perundungan yang dialami oleh anak sendiri secara langsung baik secara fisik atau psikis. Pada peristiwa keluarga retak, emosi negatif muncul disebabkan karena menyaksikan konflik interpersonal atau kekerasan yang terjadi antara kedua orang-tua yang merupakan significant other bagi mereka. Rasa cemas yang khas berupa kecemasan dan rasa tidak berdaya akan masa depan keluarga, khawatir hilangnya dukungan sosial dari orang-tua atau keluarga (Amato \& Keith, 1991), dilema antara rasa benci dengan rasa sayang terhadap orang-tua, gejala depresif serta kecemasan akan kehilangan cinta kedua orang tua adalah reaksi emosi yang umumnya terjadi pada anak dalam keluarga retak (Lee \& Bax, 2002; Kelly, 2003).

Sehingga, memastikan bahwa anak yang mengalami keluarga retak dapat merefleksikan peristiwa keluarga retak yang dialaminya dengan perspektif yang lebih positif (munculnya insight, makna, hikmah, pembelajaran) bagi kehidupannya menjadi kunci bagi adaptif atau tidaknya refleksi diri yang dilakukannya. Dengan demikian bagaimana cara memunculkan perspektif yang lebih positif yang mendorong kepada pemaknaan dan insight, pada saat refleksi-diri menjadi hal yang penting dalam konteks ini. Melakukan refleksi-diri tentang peristiwa negatif akan membangkitkan reaktivitas emosi. Reaksi emosi yang dirasakan saat merefleksikan peristiwa negatif, umumnya sangat intens sehingga mendorong perspektif egosentris, atau memandang peristiwa negatif hanya dengan sudut pandang dirinya (NolenHoeksema, Wisco, \& Lyubomirsky, 2008), dan ini menyebabkan individu larut dengan emosi negatifnya sendiri, tanpa mampu memaknai dengan kepala dingin. Demikian pula reaksi emosi pada anak yang menghadapi peristiwa keluarga retak.

Meskipun telah ada beberapa studi tentang bagaimana melakukan refleksi diri untuk melewati peristiwa negatif dengan lebih adaptif, yakni dengan cara menggunakan perspektif yang non-egosentris (perspektif pengamat). Namun, studi-studi refleksi diri yang menyatakan bahwa perspektif non-egosentris (perspektif pengamat) mampu mendorong individu untuk tidak larut pada emosi negatifnya tersebut belum pernah dilakukan secara spesifik pada konteks keluarga retak. Studi-studi refleksi diri adaptif tersebut, umumnya dilakukan pada konteks peristiwa negatif yang berefek langsung pada individu seperti konflik interpersonal (Kross dkk, 2005; Ayduk \& Kross, 2008), kecemasan menghadapi tantangan untuk tampil di depan umum (Kross dkk, 2014), atau pengelolaan tekanan emosi yang tidak terkait dengan keluarga retak (Ayduk \& Kross, 2010).

Beberapa studi tentang refleksi diri adaptif tersebut (Ayduk \& Kross, 2008; Ayduk \& Kross, 2010) menyebutkan bahwa perspektif pengamat yang difasilitasi kata ganti nama-diri atau non pertama, akan mendorong refleksi diri adaptif. Sebaliknya, hasil non-adaptif diperoleh jika refleksi diri dilakukan dengan perspektif pelaku yang difasilitasi dengan penggunaan kata-ganti pertama. Hasil penelitian tersebut berlawanan dengan studi-studi refleksi diri (melalui menulis ekspresif) yang menyatakan bahwa penggunaan perspektif pelaku yang difasilitasi kataganti personal pertama dapat memberikan efek yang adaptif (Pennebaker \& Chung, 2007; Kross, dkk., 2014). Sehingga, dapat dikatakan masih terdapat celah penelitian pada riset dengan topik refleksi diri adaptif, yakni: apakah refleksi diri adaptif difasilitasi oleh penggunaan perspektif pengamat (menggunakan kata ganti personal nama-diri atau kata-ganti non-pertama) atau difasilitasi oleh penggunaan perspektif pelaku (menggunakan kata ganti personal pertama).

Secara bersama-sama dapat dikatakan bahwa masih terdapat kesenjangan teoretik terkait mekanisme refleksi diri adaptif yakni: 1) belum pernah diteliti secara spesifik dalam konteks keluarga retak, serta 2) masih terdapat perdebatan tentang penggunaan perspektif: apakah perspektif pengamat ataukah perspektif pelaku, ataukah kedua-duanya dapat dipergunakan dan memberi dampak yang adaptif dengan mekanisme yang berbeda-beda? Untuk menjawab pertanyaan penelitian bagaimana gambaran atau mekanisme refleksi diri adaptif pada individu yang mengalami keluarga retak dari sisi penggunaan bahasa (penggunaan perspektif pengamat vs perspektif pelaku), maka dilakukan penelitian yang bertujuan untuk menjelaskan bagaimana proses refleksi diri adaptif individu yang mengalami keretakan keluarga, dilihat dari hasil tulisan individu yang menulis narasi dengan menggunakan kata ganti personal satu dan individu yang menulis dengan kata ganti personal nama-diri.

Refleksi diri dibahas pertama kali oleh Dewey (1933 h.45),yang mendefinisikannya sebagai "Active, persistent, and careful consideration of any belief or supposed form of knowledge in the light of the grounds that support it, and the further conclusions to which it tends, constitutes reflective thought." Lebih lanjut lagi, ia mengatakan bahwa ada dua elemen penting dalam refleksi yakni: a) keadaan bingung, ragu-ragu, tidak stabil; dan (b) tindakan pencarian atau investigasi diarahkan untuk mengungkap fakta lebih lanjut dimana ini berfungsi untuk menguatkan atau membatalkan keyakinan yang ada. Sehingga dapat dikatakan bahwa refleksi diri umumnya dipicu oleh problem dan ketidakstabilan baik yang berasal halhal di luar diri maupun dari dalam diri, diantaranya adalah peristiwa keluarga retak.

Refleksi diri akan mendorong individu untuk fokus pada pengalaman dirinya dan reaksi terhadap pengalaman tersebut (Silvia, Eichstaedt, \& Phillips, 
2005). individu bisa saja berhasil atau gagal ketika berusaha memahami perasaan negatifnya. Kegagalan individu saat berusaha memahami perasaan negatifnya disebabkan karena justru larut pada perasaan negatifnya sendiri tanpa dapat menemukan solusi atau makna atas perasaan tersebut (Mor \& Winquist, 2002; Nolen-Hoeksema dkk, 2008). Umumnya, karena individu larut pada emosi negatif dan kemudian tidak menemukan solusi ataupun makna, individu memilih untuk menghindar dari usaha untuk memahami perasaan negatifnya tersebut (Feldner, Zvolensky, Eifert, \& Spira, 2003; NolenHoeksema dkk, 2008),

Sehingga pertanyaannya adalah, bagaimana seseorang dapat berhasil mendapatkan efek refleksi diri yang adaptif? Menurut konsep menjaraki-diri, refleksi diri adaptif terjadi ketika seseorang dapat menciptakan jarak mental antara dirinya dengan stimulus (peristiwa negatif) dengan cara mengadopsi perspektif pengamat (Bahiyah \& Savitri, 2018; Kross \& Ayduk, 2017; Kross \& Grossman, 2011). Refleksi diri adaptif didefinisikan sebagai refleksi diri yang berkurang dalam intensitas reaktivitas emosi, berkurang dalam bercerita berulang, berkurang dalam penghindaran serta mendapatkan pemaknaan kembali melalui mekanisme menjaraki-diri (self distancing). Mekanisme ini disamakan dengan proses mencari nasihat atau masukan dari orang lain tentang peristiwa negatif yang dihadapi. Seseorang yang mengalami peristiwa negatif seringkali kesulitan untuk berpikir secara obyektif tentang keadaan mereka sendiri, namun umumnya orang lain dapat memberikan pendapat lain, atau pandangan yang berbeda, misalnya nasihat bijak yang lebih obyektif dan tidak emosional (Grossman \& Kross, 2014).

Cara bercerita atau menulis narasi pada saat refleksi diri (Kross dkk, 2014) adalah salah-satu tanda berbahasa (linguistic marker) yang dapat menjadi salah satu petunjuk untuk adaptif atau tidaknya kondisi psikologis seseorang (Graybeal, Sexton \& Pennebaker, 2002; Pennebaker \& Seagal, 1999). Terkait dengan metode bercerita, jika dibandingkan dengan memikirkan permasalahan saja, bercerita lisan ataupun menulis tentang permasalahan yang sedang dihadapi, memiliki kemanfaatan bagi kesehatan mental yang lebih baik (Nolen-Hoeksema dkk, 2008). Efek yang ditimbulkan dari menulis adalah keterbukaan diri yang berkaitan erat dengan kesehatan mental (Pennebaker \& Chung, 2007).

Selama ini dikenal beberapa metode menulis diantaranya adalah menulis naratif (menulis dengan struktur bercerita -awal, tengah, akhir-) dan menulis ekspresif (menulis dengan cara mengekspresikan emosi, tanpa terlalu mempertimbangkan struktur). Metode-metode tersebut telah diketahui manfaatnya bagi kesehatan psikologis sejak beberapa dekade belakangan ini (Niles dkk., 2015; Pennebaker \& Chung, 2007). Manfaat menulis naratif dan menulis ekspresif telah banyak diteliti dan menghasilkan bukti yang beragam. Ada peneliti yang menemukan bahwa keduanya memberikan manfaat psikologis yang sama (Danoff-Burg, 2016) dengan mekanisme psikologis yang berbeda (Nazarian \& Smyth, 2013). Ada pula peneliti yang menyatakan bahwa menulis naratif dengan menggunakan kata ganti personal orang ketiga (diri sebagai pengamat: menggunakan: nama diri atau dia, ia) memiliki efek psikologis yang lebih baik dibanding dengan menulis dengan kata ganti personal orang pertama (diri sebagai pelaku: saya, aku) (Margola, Travagin, \& Lawrence, 2018). Konsep yang disebut terakhir sejalan dengan penelitian yang dilakukan Kross (2016) yang menyatakan bahwa refleksi diri individu terkait peristiwa negatif yang pernah dialaminya jika refleksi dirinya adaptif, terdapat mekanisme menjaraki-diri (self-distancing) di dalamnya, disebabkan karena mengadopsi perspektif orang ketiga.

Berdasarkan penjelasan di atas, penelitian ini secara rinci bermaksud menggambarkan bagaimana proses refleksi diri adaptif sebagai perilaku yang berguna dalam merespon pengalaman negatif individu. Untuk itu penelitian ini akan menyajikan gambaran refleksi diri individu yang mengalami peristiwa keluarga retak, melalui isi tulisan yang dihasilkan oleh subyek yang mengalami keluarga retak. Individu yang mengalami keluarga retak tersebut, menulis refleksi diri dengan menggunakan kata ganti personal pertama: saya (perspektif dirisendiri) dan menulis refleksi diri dengan menggunakan kata ganti personal ketiga: nama-diri (perspektif pengamat)

\section{Metode Penelitian}

\section{Desain Penelitian dan Prosedur}

Pendekatan penelitian ini adalah kualitatif dengan menggunakan metode analisis isi, sebuah metode untuk menganalisis data yang berasal dari tulisan, lisan, atau pesan komunikasi visual (Cole, Maxwell, Dukewich, \& Yosick, 2010). Sifat dari analisis ini adalah sistematik, obyektif dalam penggambaran dan menguantifikasi fenomena (Krippendorff, 1991). Metode ini digunakan untuk menguji teori atau konsep untuk meningkatkan pemahaman tentang data dengan cara menyaring (mereduksi) kalimat menjadi kategori konten yang lebih sedikit. Metode ini juga mengasumsikan dan mengklasifikasikan kalimat, frasa, kata ke dalam konsep teori tertentu (Cavanagh, 1997). Analisis isi dapat digunakan secara induktif yakni berangkat dari data yang ada untuk membangun konsep atau model baru atau dengan pendekatan deduktif, yang berasal dari asumsi teori untuk tujuan mengonfirmasi (Elo \& Kyngas, 2008).

Pendekatan analisis dalam penelitian ini adalah pendekatan deduktif, yakni mengonfirmasi faktor-faktor refleksi diri adaptif yang terdapat pada teks, dengan kalimat sebagai unit analisisnya. Adapun tema-temanya antara lain: narasi pemaknaankembali (yaitu narasi yang berisi pemaknaan terhadap peristiwa keluarga retak), narasi bercerita- 
berulang (yaitu.narasi tanpa pemaknaan, hanya mengulang-ulang cerita), kata-kata emosi positif, kata-kata emosi negatif dan kata atau kalimat penghindaran (yaitu, narasi yang menunjukkan individu menekan atau menghindar dari emosi yang dirasakan). Sifat dari analisis data adalah bersifat kualitatif dalam interpretasi kalimat, apakah termasuk tema bercerita berulang, pemaknaankembali, emosi negatif atau emosi positif, atau penghindaran. Lalu, setelah itu dilakukan kuantifikasi dengan menghitung jumlah frekuensi dari kemunculan unit kalimat yang cocok dengan tematema tersebut. Kredibilitas dalam analisis data dalam penelitian ini, dilakukan dengan metode inter-rater coding atau inter-rater confirmation, yakni konfirmasi antara dua independen rater untuk mengobjektifikasi data.

Data teks yang ditelaah dalam penelitian ini adalah teks yang berasal dari partisipan eksperimen menulis naratif yang dilakukan selama 4 (empat) hari berturut-turut. Partisipan masuk ke dalam 2 (dua) jenis kelompok yang memiliki dua instruksi yang berbeda. Kelompok pertama adalah kelompok perspektif pelaku yang menggunakan kata ganti personal pertama (saya, aku). Instruksi pada kelompok satu adalah: Bagaimana pun manusia berusaha untuk tenang dan tetap berperasaan positif, akan ada selalu saat-saat dimana kita merasakan perasaan negatif seperti cemas, sedih, marah, kecewa, ketika sebuah peristiwa sulit menimpa diri kita. Tutuplah mata Anda dan cobalah mengingat peristiwa sulit yang pernah Anda alami dan mengingat kembali seolah-olah Anda mengalami kembali dan berada pada waktu itu, sebagai pelaku atau seseorang yang mengalami peristiwa itu kembali (perspektif Anda sebagai orang yang mengalami). Pikirkanlah mengapa Anda merasakan perasaan yang Anda rasakan saat itu, Pikirkanlah dengan perspektif Anda sendiri. Ambilah waktu Anda secara cukup untuk kembali mengingat pada saat Anda mengalami peristiwa sulit tersebut selama 1 menit, tulislah dengan menggunakan kata ganti personal saya atau aku.

Sedangkan kelompok kedua adalah kelompok pengamat yang menggunakan kata ganti personal ketiga (nama diri) atau perspektif pengamat untuk merepresentasikan dirinya. Instruksi: Bagaimana pun manusia berusaha untuk tenang dan tetap berperasaan positif, akan ada selalu saat-saat dimana kita merasakan perasaan negatif seperti cemas, sedih, marah, kecewa, ketika sebuah peristiwa sulit menimpa diri kita. Tutuplah mata Anda dan cobalah mengingat peristiwa sulityang pernah Anda alami dan mengingat kembali seolah-olah Anda mengalami kembali dan berada pada waktu itu, sebagai pengamat atau seseorang berjarak dan sedang mengamati diri Anda sendiri yang sedang mengalami peristiwa itu (perspektif Anda sebagai orang yang mengamati diri sendiri). Pikirkanlah mengapa Anda yang Anda amati, merasakan perasaannya saat itu, Pikirkanlah dengan perspektif pengamat. Ambilah waktu secara cukup untuk kembali mengingat pada saat Anda mengalami peristiwa sulit tersebut selama 1 menit, lalu tulislah dengan menggunakan kata ganti nama diri Anda atau Anda sebagai pengamat

\section{Partisipan}

Partisipan (mahasiswa sebuah universitas swasta di Jakarta) yang memilih topik keluarga retak berjumlah 10 orang dari total 92 peserta pelatihan menulis naratif. Pada pelatihan tersebut, partisipan (usia 15 sampai 25 tahun) diminta untuk menulis secara naratif dengan topik peristiwa negatif (dalam hal ini keluarga retak) dengan menggunakan perspektif pelaku (kata ganti personal saya atau aku) dan perspektif pengamat (kata ganti personal nama diri), sebagaimana instruksi pada paragraf sebelumnya. Penulisan dilakukan selama 4 hari berturut-turut dengan durasi 30 menit per-hari. Setelah dilakukan cek pada naskah hanya 7 partisipan yang mengikuti instruksi menulis dengan benar. Sehingga jumlah partisipan yang naskahnya diteliti hanyalah 7 naskah.

\section{Analisis Data}

Peneliti memilih naskah yang bertema keluarga retak dari keseluruhan naskah dan ditemukan 10 naskah. Dari 10 naskah tersebut, 7 naskah menulis dengan sesuai instruksi. Peneliti kemudian melakukan koding pada pada narasi partisipan, dengan menggunakan unit kalimat. Kode pertama diletakkan pada akhir unit kalimat: inisial subyek, diikuti angka mewakili urutan hari, angka mewakili urutan paragraf, lalu angka mewakili urutan kalimat (contoh. DV.1.1,2). Lalu dilakukan koding tematik berdasar unit kalimat yang dikategorikan menjadi 5 tema: 1) Tema pemaknaan kembali (cont. "Beberapa bulan seterusnya SS terus mencoba untuk survive dan nerima keadaan (SS.4.1.1)), 2) Tema bercerita berulang (cont. yang ada dipikiran saya saat itu hanya kenapa ayah saya tega, kenapa ayah saya yang selalu saya bangga-banggakan akhirnya seperti ini (DV.2.3.2). Kenapa? Saya terus saja berpikir seperti itu (DV.2.3.3), 3) tema emosi positif (cont. Menjalani hidup dan saling melengkapi (GZ.4.7.9), 4) tema emosi negatif (cont. Membuatku makin tak dapat berhenti menangis sepanjang waktu hingga mama sampai di tempat peristirahatan terakhirnya (GZ.4.7.3), dan 5) tema penghindaran (cont. Bahkan aku lebih suka pergi ke sekolah karena aku merasa akan melupakan segalanya sejenak, seperti ada perasaan aneh ketika pulang ke rumah rasa takut membayangkan apa yang akan terjadi selanjtnya (GZ.2.5.6).

Dua rater independen yang telah dilatih untuk menilai kalimat sesuai 5 kategori tema tanpa mengetahui tujuan penelitian, melakukan koding tematik. Lalu dilakukan validasi antar rater secara kualitatif data yakni mendiskusikan hasil koding secara bersama antara dua rater independen bersama peneliti, untuk menegakkan obyektifitas. Lalu dilakukan penghitungan kemunculan kategori tema secara frekuentif pada masing-masing tema dengan satuan persentase. Kemudian disusun 
pembahasan dan analisis deskriptif kuantitatif dengan unit kalimat, serta menarik kesimpulan.

\section{Hasil Penelitian}

\section{Kualitatif}

Hasil penelitian menunjukkan bahwa tidak seluruh partisipan melewati proses refleksi diri secara adaptif selama menulis. Berdasarkan perbedaan instruksi perspektif pengamat dan perspektif pelaku, terdapat 2 subyek pada kelompok dengan instruksi menulis perspektif pelaku yakni: DV dan BM yang tidak menunjukkan tanda-tanda refleksi diri adaptif. Sedangkan 5 subyek lainnya baik dari kelompok perspektif pengamat yakni SS, GZ dan OB, serta kelompok perspektif pelaku SE dan LM semuanya menunjukkan tanda-tanda refleksi diri adaptif.

Analisis data dilakukan dengan analisis tematik dengan unit kalimat dengan tema-tema sebagai berikut : 1) kalimat pemaknaan kembali 2) bercerita berulang, 3) kalimat positif, 4) kalimat negatif, dan 5) kalimat penghindaran. Analisis konten dicukupkan pada saat seluruh naskah yang dianalisis (7 naskah) tidak menunjukkan penambahan informasi baru (saturated) berdasarkan teori refleksi diri adaptif yang difasilitasi oleh menjaraki-diri (Kross dkk, 2005). Metode saturasi yang digunakan mengacu pada apriori thematic saturation (Saunders, dkk., 2017) yang didasarkan pada tujuan awal penelitian serta metode analisis konten yang bersifat deduktif (bukan induktif). Sehingga, ketika tema-tema yang ditemukan sudah berdasarkan konsep teori yang ditetapkan, analisis terhadap data dihentikan karena dianggap sudah jenuh (saturated). Proses analisis 7 naskah dihentikan ketika sudah tidak ditemukan lagi tema yang baru berdasarkan teori yang digunakan sebagai panduan. Dapat dikatakan bahwa analisis terhadap 7 naskah tulisan partisipan tersebut telah dikatakan mencapai saturasi.

Data deskriptif berdasarkan pembagian kelompok instruksi menulis (instruksi perspektif pelaku vs perspektif pengamat), usia, jenis kelamin, suku bangsa, waktu perceraian, disajikan dalam tabel
1. Dinamika psikologi refleksi diri adaptif disajikan dengan menggunakan pembedaan berdasarkan perspektif yang digunakan pada saat menulis naratif, dan berdasarkan tema-tema yang merupakan faktorfaktor refleksi diri adaptif (kalimat pemaknaan kembali, emosi positif, kalimat bercerita berulang, emosi negatif dan penghindaran).

Reconstruing, pemaknaan dan emosi positif pada kelompok perspektif pengamat. Kelompok pengamat (SS, GZ, OB) yang menuliskan narasinya dengan sudut pandang pengamat (menggunakan kata ganti: nama diri atau diri-saya), ditemukan menuliskan narasi pemaknaan-kembali atau mendapatkan insight, dan solusi pada hari keempat serta emosi positif. SS menulis kalimat-kalimat pemaknaan kembali pada hari keempat sebagai berikut:
"Beberapa bulan seterusnya SS terus mencoba untuk survive dan nerima keadaan (SS.4.1.1). Karena SS tdk mau merasa terus tertekan dengan hal tsb (SS.4.1.2). SS tdk mau hal tsb menjadi beban selama hidup (SS.4.1.3). Paman pernah menyampaikan kepada SS bahwa SS tidak boleh membenci ayah maupun ibunya, karena bagaimanapun mereka adalah orang tua SS, tidak ada yang namanya "mantan anak" di keluarga (SS.4.1.4). SS mencoba untuk menanamkan itu di hidup SS (SS.4.1.5)."

GZ yang semula melihat ibunya hancur karena perceraian dengan ayahnya, tetapi kemudian melihat perubahan sikap ibunya, menulis kalimat-kalimat pemaknaan-kembali, dan kalimat positif pada hari keempat sebagai berikut: "Mencoba mengikhlaskan segala sesuatu yang
terjadi Sebagai rancangan yang memang
Tuhan atur dalam kehidupan kami (GZ.4.2.1).
Aku melihat diriku yang diam-diam
menjadi kagum dengan mama (GZ.4.2.2).
aku melihat diriku yang mengagumi mama
karena Ia mampu menata hatinya yang
hancur bersabar dan berubah menjadi
wanita yang menginspirasi (GZ.4.2.3)."

Tabel 1. Deskripsi Partisipan

\begin{tabular}{|c|c|c|c|c|c|c|c|}
\hline & Subjek 1 & Subjek 2 & Subjek 3 & Subjek 4 & Subjek 5 & Subjek 6 & Subjek 7 \\
\hline Nama (Inisial) & $\mathrm{SS}^{*}$ & $\mathrm{OB}$ & $\mathrm{DV}$ & $\mathrm{BM}$ & GZ & LM & $\mathrm{SE}$ \\
\hline $\begin{array}{l}\text { Kelompok Instruksi } \\
\text { Menulis }\end{array}$ & Pengamat & Pengamat & Pelaku & Pelaku & Pengamat & Pelaku & Pelaku \\
\hline Jenis Kelamin & Perempuan & Laki-laki & Perempuan & Laki-laki & Perempuan & Perempuan & Perempuan \\
\hline Usia & 23 Tahun & 25 Tahun & 20 Tahun & $\begin{array}{l}22 \\
\text { Tahun }\end{array}$ & 21 Tahun & 19 Tahun & 21 Tahun \\
\hline Suku Bangsa & Jawa & Madura & Jawa & Sunda & Jawa & Jawa & Jawa \\
\hline $\begin{array}{l}\text { Orangtua bercerai sejak } \\
\text { usia }\end{array}$ & Remaja & Sejaklahir & 19 Tahun & 8 Tahun & 8 Tahun & 10 Tahun & 2 Tahun \\
\hline
\end{tabular}


OB yang sempat lari dari rumah, karena tertekan dengan perceraian orang-tuanya, pada hari keempat menuliskan reconstruing, pemaknaan dan kalimat positif sebagai berikut:

"Saya mengamati diri-saya yang merasakan kasih sayang teman-teman sekolah kepada saya, support yang diberikan membuat saya kuat dan percaya diri untuk kembali ke sekolah (0.B.4.5.9). Anggota keluarga saya berhasil membuat mediasi antara saya dan ibu saya dan membuat hubungan kami kembali rukun, akhirnya saya mengiyakan untuk pulang dan kembali kerumah (O.B.4.5.10). Selepas kejadian itu saya melihat bahwa saya mencoba lebih memahami ibu saya dan mentoleransi kekurangan dan saya juga menyadari kekurangan saya yang kadang tidak bisa selalu menyenangkan hati ibu saya (O.B.4.5.11)."

Pada narasi pemaknaan kembali peristiwa keluarga retak yang dialami, baik SS, GZ dan OB memunculkan tema khas yakni adanya dukungan sosial dari keluarga. Narasi SS memunculkan tokoh Paman yang mendorongnya untuk dapat menerima perpisahan orang-tuanya dengan mengatakan 'tidak ada mantan anak', pada narasi GZ pemaknaan kembali yang adaptif didorong dukungan sosial Ibu, juga oleh kekagumannya pada sosok Ibu, yang sabar dan menginspirasinya. Narasi OB, juga menampakkan adanya dukungan sosial anggota keluarga yang memediasi hubungan OB dengan ibunya.

Reconstruing, pemaknaan dan emosi positif pada kelompok perspektif pelaku. Pada kelompok yang menggunakan perspektif pelaku (menggunakan kata ganti personal pertama -saya atau aku-) yakni: DV, BM, LM dan SE, hanya LM dan SE yang menuliskan narasi pemaknaan kembali. Sementara DV dan BM tidak menampakkan proses pemaknaan kembali, melainkan terus-menerus ter-fiksasi pada emosi negatif berupa kekecewaan dan kebencian pada peristiwa yang dialamnya, pada DV terutama pada ayahnya, sebagaimana narasi di bawah ini :

"Dan akhirnya sampai sekarang saya tidak mempunyai solusi bagaimana cara agar saya bisa menerima ayah saya seperti dulu lagi (DV.4.4.6)."

Pada BM narasi memunculkan kerinduan akan sosok ayah yang dibarengi dengan emosi sedih, kesal dan benci:

"Saya memiliki ayah namun di anggap ayah saya sudah tidak ada (B.M.4.2.10). Saya merasakan rindu tapi juga kesal benci (B.M.4.2.11). Saya ingin memiliki sosok ayah namun untuk membayangkannya saja saya tidak bisa (B.M.4.2.12)."
Sedangkan pada LM muncul kalimat pemaknaan kembali berupa harapan pada hari keempat:

"Semoga jangan sampai ketika aku menikah nanti, aku melakukan kesalahan hingga aku harus bercerai (LM.4.1.11.3). Aku tidak mau anakku merasakan menjadi aku sekarang (LM.4.1.11.4). Intinya, sampai detik ini, aku hanya ingin bahagia bersama papa. Hanya berdua (LM.4.1.11.5). Hanya ada aku dan papa tidak ada yang lain (LM.4.1.11.6)."

Khususnya pada LM narasi pemaknaan kembali muncul bahkan sejak dari hari pertama, walaupun ia termasuk kelompok pelaku yang menggunakan kata ganti personal pertama, yang umumnya larut dan tidak berjarak dengan diri dan peristiwa yang dialaminya. Pada LM karena ia menggunakan gaya bahasa kilas balik (Danoff-burg, 2016) dan memberikan pemaknaan "menerima", sejak di hari pertama menulis:

"Pertama kali saya mendapatkan peristiwa sulit dalam hidup saya itu ketika saya harus menerima keadaan bahwa ternyata kedua orang tua saya tidak dapat bersama kembali (LM.1.1.1)."

Paragraf di atas adalah paragraf kilas balik, yakni kesimpulan dari kisah yang akan dituliskannya. Baru kemudian ia menuliskan rangkaian kejadian yang berakhir pada kesimpulan tersebut. Gaya berbahasa kilas balik dalam beberapa penelitian dengan topik menjaraki-diri, dikategorikan sebagai gaya bahasa yang berjarak (distancing language). Sebab umumnya, penulis sudah menuliskan pemaknaan di awal narasi yang akan ditulisnya, sebagaimana LM yang mengawali tulisannya dengan kata: menerima. Gaya penulisan LM berbeda dengan individu pada kelompok pelaku lainnya yang tidak menuliskan pemaknaan di hari pertama penulisan, sebagaimana paragraf contoh di atas.

Pada SE muncul narasi pemaknaan kembali berupa pemaafan dan penerimaan di hari keempat:

"Sebelum saya dapat memahami ayah saya (SE.4.2.1). Bunda saya-lah yang membuat saya mau membuka diri kepada ayah saya (SE.4.2.2). Bunda saya mengatakan hal-hal logis yang dapat saya pahami Sehingga saya akhirnya mau dan berusaha memperbaiki hubungan saya dengan ayah saya (SE.4.2.3). Saya memaafkan ayah saya, saya berbicara dengan ayah saya tentang kemarahan saya (SE.4.3.1). Hubungan kami pun membaik hingga sekarang (SE.4.3.2)."

Meskipun menggunakan perspektif pelaku, SE tampak menulis kalimat pemaknaan kembali yang cukup banyak, bahkan sejak hari pertama terutama ketika menuliskan tentang perasaannya terhadap 
ibunya. Ia menggunakan pilihan kata abstrak (Mischel \& Shoda, 2014) yang merupakan bahasa berjarak (distancing language) untuk menggambarkan ibunya:

"Saya selalu merasa aman dan disayangi oleh ibu saya (SE.1.2.5). Ibu saya merupakan sosok ibu yang tangguh dan kuat (SE.1.2.6)."

Pilihan kata abstrak (bukan kongkret): aman, tangguh, dan kuat untuk menggambarkan ibunya pada hari pertama penulisan serta kecenderungan untuk tidak berpusat pada dirinya (egosentris), menjelaskan mengapa SE walaupun menggunakan perspektif pelaku, namun mampu menuliskan kalimat pemaknaan kembali lebih banyak. Sebagaimana dikatakan oleh Kross (2016), penulisan yang tidak menggunakan perspektif egosentris akan meningkatkan refleksi diri adaptif

Berdasarkan konten pemaknaan kembali pada kelompok yang menggunakan perspektif pelaku tersebut, pada subyek yang dapat melakukan refleksidiri adaptif (LM dan SE) juga muncul tema dukungan sosial, tetapi tema tersebut tidak muncul pada subyek yang tidak dapat melakukan refleksi-diri adaptif (DV dan BM). Pada narasi subyek LM, tema dukungan sosial muncul dari sosok ayah dimana perilaku ayah yang baik kepada LM menyebabkan ia ingin selalu bersama dengan ayahnya. Sedangkan pada narasi SE, dukungan sosial berasal dari Ibunya. Ia menulis bahwa meskipun orang-tuanya sudah bercerai, ibu SE yang memberikan pemahaman tentang ayahnya, sehingga SE pada akhirnya dapat menerima kembali ayahnya.

Tema bercerita berulang dan emosi negatif. Muncul pada seluruh partisipan, baik dari kelompok pelaku dan kelompok pengamat, mulai hari pertama hingga hari keempat menulis naratif. Proses ini wajar, karena merupakan 'jembatan' yang pada akhirnya sampai pada proses pemaknaan kembali. Persoalannya adalah jika proses pra-reflektif ini tidak berujung pada proses refleksi adaptif berupa pemaknaan kembali, dan emosi positif, sebagaimana terjadi pada subyek DV :

"Kenapa? Saya terus saja berpikir Seperti itu (DV.2.3.3). Saya berfikir kalau keluarga saya berantakan, kalau ayah dan ibu saya sampai pisah maka saya bukanlah orang yang beruntung, saya sama dengan beberapa teman saya yang keluarganya pun hancur (DV.2.3.4)."

Pertanyaan berulang, mempertanyakan mengapa hal itu terjadi pada keluarganya terus menerus dilakukan DV hingga hari ke-empat:

"Pada saat itu sebenarnya saya kasihan melihat ayah saya bingung, terpuruk juga, tetapi bagaimana dengan ibu saya? Ibu saya jauh lebih sakit daripada apa yang ayah saya rasakan (DV.4.1.3)."

"Entah kenapa juga sampai detik ini saya tidak bisa bercanda atau mengobrol seperti biasa bersama ayah saya, saya pun pada saat itu berfikir mungkin saya terlalu sakit hati (DV.4.4.3).Dan akhirnya sampai sekarang saya tidak mempunyai solusi bagaimana cara agar saya bisa menerima ayah saya seperti dulu lagi (DV.4.4.6)."

Dan bercerita berulang terus-menerus ditulisan serta emosi negatif, bahkan hingga hari keempat dan akhir cerita, dituliskan oleh BM:

"Saya merasa seperti kehilangan sosok ayah dalam hidup saya, saya seperti tidak pernah menganggap ada sosok ayah dalam hidup saya (B.M.4.1.1). Namun tetap saja saya marah dengan ayah saya, saya kesal begitu kesal (B.M.4.2.2). Saya tidak bisa melihat ibu saya menangis(B.M.4.2.3). Saya memiliki ayah namun menganggap ayah saya sudah tidak ada (B.M.4.2.10). Saya merasakan rindu tapi juga kesal benci (B.M.4.2.11)."

Tema Penghindaran. Muncul tidak hanya pada kelompok perspektif pelaku ( DV, BM, LM, SE) tetapi juga kelompok perspektif pengamat (SS, OB, GZ).

Pada SS, penghindaran dilakukan dengan melakukan distraksi lebih memilih berkumpul dengan teman-temannya

"SS pun mulai merasa tak nyaman dan lebih sering menghabiskan waktu dengan teman2 (SS.3.2.3). SS bingung mengapa ada hal2 yang sulit sekali seolah seperti menahan diri SS untuk bersikap Seperti dulu lagi(SS.4.4.3). Sering Sekali SS mencoba untuk memulai tapi Selalu gagal (SS.4.4.5)."

Demikian pula pada GZ,

"Seperti menyadari bahwa sesuatu telah terjadi diantara orang tuaku, Seperti mengetahui ada Sesuatu yang ditutupi mamaku tetapi aku melihat diriku Selalu bersikap biasa Seolah tak ada apa- apa karena aku tak tahu apa yang harus kuperbuat (GZ.2.2.6). Bahkan aku lebih suka pergi ke sekolah karena aku merasa akan melupakan segalanya sejenak, seperti ada perasaan aneh ketika pulang ke rumah rasa takut membayangkan apa yang akan terjadi selanjutnya(GZ.2.5.6)."

Demikian pula OB yang menekan keingintahuannya tentang sikap ayahnya saat datang ke perkemahan tempatnya berkegiatan:

“Kejadian ini pun berakhir setelah perkemahan dan masih menyisakan kejanggalan dalam diri saya, namun saya tidak begitu banyak mencari tahu dan ambil pusing (O.B.1.5.1). “ 
Tabel 2. Tabel Jumlah Frekuensi Unit Kalimat yang Mewakili Tema Refleksi diri Adaptif

\begin{tabular}{|c|c|c|c|c|c|c|c|c|c|}
\hline & & \multicolumn{8}{|c|}{ Total Frekuensi } \\
\hline & & $\begin{array}{l}\text { Subjek } \\
\text { SS (A) }\end{array}$ & $\begin{array}{l}\text { Subjek } \\
\text { OB (A) }\end{array}$ & $\begin{array}{l}\text { Subjek } \\
\text { DV (P) }\end{array}$ & $\begin{array}{l}\text { Subjek } \\
\text { BM (P) }\end{array}$ & $\begin{array}{l}\text { Subjek } \\
\text { GZ (A) }\end{array}$ & $\begin{array}{l}\text { Subjek } \\
\text { LM (P) }\end{array}$ & $\begin{array}{l}\text { Subjek } \\
\text { SE (P) }\end{array}$ & $\begin{array}{l}\text { Total unit } \\
\text { analisis* }\end{array}$ \\
\hline \multirow{6}{*}{$\begin{array}{l}\text { Pemaknaan } \\
\text { Kembali }\end{array}$} & Hari 1 & 3 & 2 & 0 & 0 & & 6 & 2 & 13 \\
\hline & Hari 2 & 2 & 4 & 0 & 1 & 2 & 5 & & 14 \\
\hline & Hari 3 & 2 & 2 & 0 & 1 & 3 & 2 & 5 & 15 \\
\hline & Hari 4 & 6 & 1 & 1 & 1 & 6 & 10 & 7 & 31 \\
\hline & Total & 13 & 9 & 1 & 3 & 12 & 23 & 14 & 73 \\
\hline & Persentase & $17 \%$ & $12 \%$ & $1 \%$ & $3 \%$ & $15 \%$ & $31 \%$ & $19 \%$ & $100 \%$ \\
\hline \multirow[t]{6}{*}{ Emosi Positif } & Hari 1 & 1 & & 1 & 2 & & 1 & 1 & 6 \\
\hline & Hari 2 & & & & 1 & & & & 1 \\
\hline & Hari 3 & 2 & & & & & & & 2 \\
\hline & Hari 4 & 1 & & & & 2 & 2 & & 5 \\
\hline & Total & 4 & 0 & 1 & 3 & 2 & 3 & 1 & 14 \\
\hline & Persentase & $29 \%$ & 0 & $7 \%$ & $21 \%$ & $14 \%$ & $21 \%$ & $7 \%$ & $100 \%$ \\
\hline \multirow{6}{*}{$\begin{array}{l}\text { Bercerita } \\
\text { Berulang }\end{array}$} & Hari 1 & 3 & 2 & 5 & 8 & 2 & 7 & 5 & 32 \\
\hline & Hari 2 & 7 & 3 & 5 & 3 & 5 & 1 & 6 & 30 \\
\hline & Hari 3 & 2 & 3 & 1 & 5 & 5 & 2 & 4 & 22 \\
\hline & Hari 4 & 4 & 3 & 2 & 5 & 6 & 10 & & 30 \\
\hline & Total & 16 & 11 & 13 & 21 & 18 & 20 & 15 & 114 \\
\hline & Persentase & $14 \%$ & $10 \%$ & $11 \%$ & $18 \%$ & $16 \%$ & $18 \%$ & $13 \%$ & $100 \%$ \\
\hline \multirow[t]{6}{*}{ Emosi Negatif } & Hari 1 & 2 & 2 & & 3 & 1 & & 2 & 10 \\
\hline & Hari 2 & 1 & 4 & 1 & 1 & 3 & 2 & 2 & 14 \\
\hline & Hari 3 & 3 & 2 & 2 & 2 & & 2 & 8 & 19 \\
\hline & Hari 4 & 1 & 2 & & 1 & & 6 & & 10 \\
\hline & Total & 7 & 10 & 3 & 7 & 4 & 10 & 12 & 53 \\
\hline & Persentase & $13 \%$ & $19 \%$ & $6 \%$ & $13 \%$ & $8 \%$ & $19 \%$ & $23 \%$ & $100 \%$ \\
\hline \multirow[t]{6}{*}{ Menghindar } & Hari 1 & 2 & 2 & 1 & 1 & 2 & & & 8 \\
\hline & Hari 2 & & & & & 3 & & & 3 \\
\hline & Hari 3 & 1 & & 1 & & & & & 2 \\
\hline & Hari 4 & 2 & & 1 & & & & & 3 \\
\hline & Total & 5 & 2 & 3 & 1 & 5 & 0 & 0 & 16 \\
\hline & Persentase & $31 \%$ & $13 \%$ & $19 \%$ & $6 \%$ & $31 \%$ & $0 \%$ & $0 \%$ & $100 \%$ \\
\hline
\end{tabular}

Keterangan: *Unit Kalimat ; ** (A) pengamat, ${ }^{* * *}(P)$ Pelaku

Tabel 3. Ranking tema Pemaknaan Kembali

\begin{tabular}{lllll}
\hline Tema & Ranking & Nama & Persentase & Instruksi \\
\hline & 1 & LM & $31 \%$ & Pelaku \\
Pemaknaan & 2 & SE & $19 \%$ & Pelaku \\
kembali & 3 & SS & $17 \%$ & Pengamat \\
& 4 & GZ & $15 \%$ & Pengamat \\
& 5 & OB & $12 \%$ & Pengamat \\
& 6 & BM & $3 \%$ & Pelaku \\
& 7 & DV & $1 \%$ & Pelaku \\
\hline
\end{tabular}




\section{Kuantitatif}

Berdasarkan teks masing-masing subyek selama empat hari berturut-turut, peneliti melakukan triangulasi metode untuk mengonfirmasi hasil deskripsi kualitatifnya. Metode yang digunakan adalah menghitung frekuensi kalimat berdasar tema-tema yang muncul intrasubjek, kemudian dilakukan komparasi intersubjek. Perhitungan frekuensi kalimat berdasarkan tema, dihitung dengan rumus sebagai berikut:

Total kalimat per-tema pada setiap subyek

To $100 \%$

Total kalimat per-tema seluruh subyek

Gambar 1. Rumus perhitungan frekuensi kalimat

Berdasarkan tabel 2. Dilakukan pemeringkatan untuk mendapatkan pola dari masing-masing instruksi menulis. Pada tabel 3. Didapatkan pola pemaknaan kembali pada partisipan dengan instruksi menulis dengan perspektif pelaku (kata ganti personal pertama) dan ditemukan persentase 2 teratas yakni LM dan SE, sedangkan dua yang lain terendah, yakni BM dan DV. Sedangkan instruksi menulis dengan perspektif pengamat (kata ganti nama diri) memiliki cenderung berada di tengah-tengah. Artinya pemaknaan kembali lebih konsisten terlihat pada kelompok dengan instruksi perspektif pengamat (kata ganti nama-diri) yakni memiliki jumlah persentase pemaknaan kembali yang moderat.

Tabel 4 menunjukkan bahwa emosi positif pada instruksi menulis dengan perspektif pengamat (kata ganti nama diri) dan instruksi menulis perspektif pelaku (kata ganti personal satu) cenderung menyebar. Ada yang berada di peringkat atas dan ada yang berada di peringkat bawah. Artinya, kedua instruksi terlihat tidak memiliki pola khas dalam persentase jumlah emosi positif.

Tabel 5 menunjukkan bahwa emosi negatif pada instruksi menulis dengan perspektif pengamat (kata ganti nama diri) dan instruksi menulis perspektif pelaku (kata ganti personal satu) cenderung menyebar. Ada yang berada peringkat atas ada yang berada di peringkat bawah. Artinya, kedua instruksi terlihat tidak memiliki pola khas dalam persentase jumlah kalimat emosi negatif

Tabel 6 menunjukkan bahwa emosi bercerita berulang pada instruksi menulis dengan perspektif pengamat (kata ganti nama diri) dan instruksi menulis perspektif pelaku (kata ganti personal satu) cenderung menyebar pula. Ada yang berada di peringkat atas ada yang berada di peringkat bawah. Artinya, kedua instruksi terlihat tidak memiliki pola khas dalam bercerita berulang

Pada tabel 7 Didapatkan pola penghindaran pada partisipan dengan instruksi menulis dengan perspektif pengamat (kata ganti nama-diri). Ditemukan persentase 2 teratas, yakni GZ dan SS. Sedangkan partisipan dengan instruksi menulis pelaku berada pada peringkat dua terendah, yakni SE dan LM. Artinya, penggunaan perspektif pelaku (kata ganti personal satu) cenderung menyebabkan partisipan tidak menghindar dari emosi yang dirasakan, sedangkan pada partisipan dengan perspektif pengamat cenderung menghindar atau menekan emosi yang dirasakan.

Berdasarkan ranking pada setiap tema refleksi adaptif, dapat dikatakan bahwa tema yang menunjukkan pola yang cukup berbeda adalah pemaknaan kembali dan penghindaran. Pemaknaan kembali lebih didominasi oleh kelompok partisipan yang menggunakan perspektif pengamat (kata ganti nama diri). Sedangkan tema penghindaran lebih muncul pada partisipan dengan instruksi perspektif pelaku (kata ganti personal satu) dimana mereka lebih tidak menghindar atau menekan emosi yang dirasakan.

\section{Diskusi}

Pola refleksi diri yang adaptif, secara konsep (Kross dkk, 2014), dikatakan akan tampak pada narasi yang memiliki kalimat pemaknaan kembali yakni banyaknya insight, emosi positif, rendahnya frekuensi emosi negatif, serta berkurangnya penceritaan berulang dan penghindaran. Berdasarkan hasil analisis isi pada dua kelompok instruksi menulis (perspektif pelaku vs pengamat), kelompok yang menulis narasi dengan perspektif pelaku dominan cenderung tidak menghindar dan tidak menekan emosi yang dirasakannya (lihat tabel 7). Kelompok yang menulis dengan perspektif pelaku cenderung mencurahkan dan mengekspresikan emosinya baik emosi negatif dan positif, sehingga narasi penghindaran tidak muncul. Temuan ini sejalan dengan konsep menulis ekspresif (Pennebaker \& Chung, 2007) yang menyatakan bahwa ekspresi emosi (dengan menulis) akan mendorong individu untuk mengeksplorasi dan menghadapi emosinya sendiri, sehingga emosi yang diingatnya kembali menjadi kurang intens. Sehingga dapat dikatakan bahwa penggunaan perspektif pelaku (kata ganti personal satu) pada refleksi diri adaptif pada kelompok ini, diperoleh dari kurangnya narasi penghindaran, dan tingginya narasi yang mengekspresikan emosi.

Sedangkan narasi pada kelompok perspektif pengamat (kata ganti personal nama-diri) dominan cenderung tinggi dalam pemaknaan kembali, namun juga terdapat narasi penghindaran. Boleh jadi, dikarenakan menggunakan perspektif pengamat yakni memosisikan diri sebagai orang lain yang sedang mengamati (nama-diri), maka ekspresi dan curahan emosi cenderung ditekan, sehingga memunculkan narasi penghindaran (lihat tabel 7). Mekanisme menjaraki-diri muncul pada saat menggunakan kata ganti nama-diri, seolah-olah narator sedang mengamati orang lain sehingga kurang intens emosinya ditandai dengan kurang munculnya ekspresi emosi, namun lebih banyak menganalisis, memberi pendapat, menemukan 
Tabel 4. Rangking tema Emosi Positif

\begin{tabular}{cllll}
\hline Tema & Ranking & Nama & Persentase & Instruksi \\
\hline \multirow{3}{*}{ Emosi Positif } & 1 & SS & $29 \%$ & Pengamat \\
& 2 & BM & $21 \%$ & Pelaku \\
& 3 & LM & $21 \%$ & Pelaku \\
& 4 & GZ & $14 \%$ & Pengamat \\
& 5 & SE & $7 \%$ & Pelaku \\
& 6 & DV & $7 \%$ & Pelaku \\
& 7 & OB & $0 \%$ & Pengamat \\
\hline
\end{tabular}

Tabel 5. Rangking tema Emosi Negatif

\begin{tabular}{cllll}
\hline Tema & Ranking & Nama & Persentase & Instruksi \\
\hline \multirow{3}{*}{ Emosi Negatif } & 1 & SE & $23 \%$ & Pelaku \\
& 2 & OB & $19 \%$ & Pengamat \\
& 3 & LM & $19 \%$ & Pelaku \\
& 4 & SS & $13 \%$ & Pengamat \\
& 5 & BM & $13 \%$ & Pelaku \\
& 6 & GZ & $8 \%$ & Pengamat \\
& 7 & DV & $6 \%$ & Pelaku \\
\hline
\end{tabular}

Tabel 6. Rangking Tema Bercerita Berulang

\begin{tabular}{cllll}
\hline Tema & Ranking & Nama & Persentase & Instruksi \\
\hline & 1 & LM & $18 \%$ & Pelaku \\
Bercerita & 2 & BM & $18 \%$ & Pelaku \\
Berulang & 3 & GZ & $16 \%$ & Pengamat \\
& 4 & SS & $14 \%$ & Pengamat \\
& 5 & SE & $13 \%$ & Pelaku \\
& 6 & DV & $11 \%$ & Pelaku \\
& 7 & OB & $10 \%$ & Pengamat \\
\hline
\end{tabular}

Tabel 7. Rangking Tema Penghindaran

\begin{tabular}{cllll}
\hline Tema & Ranking & Nama & Persentase & Instruksi \\
\hline \multirow{3}{*}{ Penghindaran } & 1 & GZ & $31 \%$ & Pengamat \\
& 2 & SS & $31 \%$ & Pengamat \\
& 3 & DV & $19 \%$ & Pelaku \\
& 4 & OB & $13 \%$ & Pengamat \\
& 5 & BM & $6 \%$ & Pelaku \\
& 6 & SE & $0 \%$ & Pelaku \\
& 7 & LM & $0 \%$ & Pelaku \\
\hline
\end{tabular}

makna atas apa yang terjadi pada obyek (nama-diri) yang diamatinya, termasuk juga dapat mengungkapkan perilaku menghindar yang dilakukan.

Temuan ini berbeda dengan penelitian sebelumnya yang menemukan bahwa mekanisme menjaraki-diri, tidak memiliki kaitan dengan penghindaran (Kross dkk., 2005). Sehingga dapat dikatakan bahwa narasi penghindaran yang muncul pada kelompok dengan perspektif pengamat (namadiri) tidak menimbulkan efek maladaptif namun justru membantu memunculkan pemaknaan. Sedangkan, untuk tiga tema yang lain yakni emosi positif, emosi negatif dan bercerita berulang cenderung tidak berbeda antara kelompok yang 
menulis menggunakan perspektif pelaku (kata ganti personal satu) maupun perspektif pengamat (kata ganti nama-diri).

Kross dkk. (2014) menyatakan bahwa penggunaan perspektif pengamat akan memfasilitasi perilaku menjaraki-diri (self distancing) dan ini mendorong pada refleksi diri adaptif. Temuan dalam penelitian ini sejalan dengan konsep menjaraki-diri yang memfasilitasi refleksi diri adaptif. Refleksi diri adaptif ditandai dengan tingginya pemaknaan kembali dan emosi positif, rendahnya emosi negatif dan bercerita berulang, serta rendahnya penghindaran. Namun demikian, terdapat temuan menarik pada narasi yang menggunakan perspektif pelaku. Secara konsep, perspektif pelaku akan mendorong seseorang untuk larut pada pikiran atau emosi negatif yang merupakan respon terhadap peristiwa negatif yang dihadapinya (Nolen-Hoeksema, dkk, 2008).

Meski demikian, hal ini tidak tampak pada LM dan SE. LM dan SE mampu menjaraki-diri dengan menggunakan mekanisme tidak menghindar, terlihat pada persentase tema penghindaran. Ditemukan bahwa kedua-nya memiliki persentase 0\% dalam jumlah kalimat penghindaran. Menggunakan kata ganti personal satu atau perspektif pelaku, tampaknya mendorong keduanya untuk dapat mencurahkan perasaan atau emosi negatif tanpa menghindar. Terlihat dari besarnya persentase kalimat emosi negatif pada SE (23\%) dan LM (19\%). Ini memungkinkan keduanya melalui proses keterbukaan diri dan katarsis (Pennebaker, 1997) untuk menghadapi emosi negatif yang dirasakannya. Pada riset-riset keterbukaan diri, dikatakan bahwa menulis ekspresif menampakkan efek yang lebih signifikan pada individu yang menghambat ekspresi emosinya. Mereka menekan atau menghindar dari emosi yang dirasakannya (Traue \& Pennebaker, 1993). Menggunakan perspektif pelaku (kata ganti personal satu) mendorong individu untuk bebas mengekspresikan, mengungkapkan, dan mengidentifikasi emosinya sehingga menimbulkan efek yang melegakan. Bisa dikatakan ini adalah semacam katarsis untuk meredakan emosi

Berdasarkan hasil dan pembahasan hasil di atas, tampak bahwa instruksi menulis menggunakan perspektif pelaku (kata ganti personal pertama) dan perspektif pengamat (kata ganti personal nama diri), pada dasarnya memfasilitasi refleksi diri adaptif, namun dengan mekanisme yang berbeda. Menulis narasi keluarga retak dengan menggunakan kata ganti personal nama diri yang dilakukan SS, GZ, dan OB memperlihatkan mekanisme refleksi diri adaptif melalui proses penghindaran. Hal ini menunjukkan bahwa proses berjarak (self distancing) terjadi dengan mekanisme penghindaran, namun bukan penghindaran yang maladaptif, sebab diikuti dengan narasi pemaknaan, emosi positif dan negatif yang moderat.

"Namun sikap SS mengisyaratkan yang lain (tidak membenci kedua orangtuanya), jadilah SS mulai lebih segan dengan orang tuanya terutama ayah (SS.1.11.3). “
Kutipan di atas. Adalah contoh kalimat penghindaran, yakni tidak sama antara yang diekspresikan dengan perasaan yang sebenarnya. Namun, pada SS pemaknaannya dan emosi positifnya juga tinggi dari sisi persentasenya.

"SS hanya ingin berdamai dengan dirinya sendiri dan juga masalahnya (SS.4.2.3)."

Hal ini merupakan temuan yang berbeda dengan penelitian sebelumnya (Kross dkk, 2014). Temuan sebelumnya menunjukkan bahwa umumnya, orang yang didiagnosis mengalami stres pasca trauma cenderung secara spontan mengadopsi perspektif menghindar dari emosi yang dirasakan ketika mereka ingat pengalaman trauma. Kecenderungan ini sering dikonseptualisasikan sebagai mekanisme penghindaran maladaptif yaitu, orang dengan stres pasca trauma secara otomatis mengadopsi perspektif pengamat untuk menumpulkan rasa sakit yang terkait dengan berpikir tentang peristiwa traumatis (Berntsen, Willert, \& Rubin, 2003; Kenny \& Bryant, 2007;McIsaac \& Eich, 2004). Hal ini berbeda dengan temuan pada penelitian ini, dimana pola penghindaran yang tampak pada kalimat, ternyata diikuti pula atau paralel dengan munculnya pemaknaan kembali, dan emosi positif serta negatif yang moderat.

Sedangkan pada subyek yang menggunakan perspektif pelaku atau menggunakan kata ganti personal pertama, ditemukan juga dapat berproses dengan adaptif melalui bercerita berulang, katarsis emosi negatif, dan turunnya penghindaran. Ini tampak pada LM yang berada pada peringkat pertama persentase bercerita berulang (18\%), peringkat kedua emosi negatif (19\%), persentase pemaknaan kembali (insight) pada peringkat pertama (31\%), dan emosi positif pada peringat kedua (21\%). Temuan ini sejalan dengan penelitian menulis ekspresif (ekspresif writing) yang menemukan bahwa bercerita secara bebas (ekspresif) dengan menggunakan kata ganti personal pertama mendorong individu untuk mengatur emosinya melalui mekanisme katarsis (Pennebaker \& Chung, 2007)

Temuan lain yang menarik adalah pada konten pemaknaan kembali, muncul tema khas yang terdapat pada kedua kelompok narasi, yakni tema dukungan sosial. Pada subyek yang berhasil melakukan refleksi diri adaptif pada kedua kelompok narasi, tema dukungan sosial muncul dan tampaknya narasi ini membantu subyek untuk dapat merefleksikan peristiwa negatif tentang keluarga retak yang dialaminya dengan lebih adaptif. Pada kajian-kajian dengan topik keluarga retak, sikap orang-tua (atau salah satu diantaranya) terhadap perceraian yang dilakukan, sikap keluarga inti, maupun sikap orangtua (atau salah satu diantaranya) terhadap anak-anak korban perceraian menjadi penentu bagi keberhasilan anak-anak dalam keluarga retak tersebut untuk melewati peristiwa itu dengan lebih adaptif. 


\section{Kesimpulan}

Kesimpulan yang didapat dari hasil dan pembahasan di atas adalah, ditemukan bahwa baik menulis narasi dengan perspektif pelaku maupun perspektif pengamat, secara umum keduanya dapat memfasilitasi refleksi diri adaptif, namun dengan mekanisme yang berbeda. Pada kelompok yang menggunakan perspektif pengamat (kata ganti namadiri), refleksi diri adaptif berproses melalui menjarakidiri. Sedangkan pada kelompok pelaku (kata ganti personal satu), proses refleksi diri adaptif dilakukan melalui proses katarsis.

Temuan lain dalam penelitian ini adalah bahwa perilaku penghindaran yang pada riset-riset sebelumnya merupakan mekanisme menjaraki-diri yang maladaptif, justru ditemukan bahwa individu masih dapat memperoleh makna atas peristiwa keluarga retak yang dialaminya, dapat menuliskan kalimat dan kata dengan emosi positif, serta dapat memaknai kembali. Ini berpotensi untuk ditindaklanjuti pada riset berikutnya terkait mekanisme penghindaran dan kaitannya dengan jarak diri. Dari sisi konten pemaknaan kembali, yang merupakan salah-satu tanda refleksi diri adaptif, Pada kedua kelompok narasi, muncul narasi dukungan sosial baik dari salah-satu orang tua (pelaku perceraian), maupun dari keluarga besar (paman, anggota keluarga lain).

Keterbatasan dari penelitian ini adalah tidak disajikan secara bersama-sama dengan analisis data kuantitatif dari penelitian eksperimen, sehingga belum mendapatkan gambaran secara utuh. Sehingga, teknik ini perlu dipertimbangkan untuk dilakukan pada penelitian selanjutnya. Hal menarik yang juga perlu untuk ditindaklanjuti adalah adanya kemungkinan regulasi emosi yang unik dan berbeda pada budaya yang berbeda (Leersnyder, Boiger, \& Mesquita, 2015), serta membuka kemungkinan untuk melihat refleksi diri adaptif dalam keluarga retak yang dipengaruhi oleh perbedaan budaya. Dukungan sosial dari keluarga besar (di luar keluarga inti) bisa membantu memulihkan luka emosional anak-anak dalam keluarga retak.

\section{Daftar Pustaka}

Amato, P. R. (2000). The consequences of divorce for adults and children. Journal of Marriage and Family, 62 (2), 1269-1287.

Amato, P. R., \& Keith, B. (1991). Parental divorce and the well-being of children: A meta-analysis. Psychological Bulletin, 110(1), 26-46. doi:10.1037/0033-2909.110.1.26.

Ayduk, Ö., \& Kross, E. (2010). From a distance: Implications of spontaneous self-distancing for adaptive self-reflection. Journal of Personality and Social Psychology, 98(5), 809-829. doi:10.1037/a0019205

Bahiyah, S., \& Savitri, S. I. (2018). Validasi Struktur Internal Alat Ukur Refleksi Diri Adaptif melalui
CFA. Jurnal Psikologi, 45(2), 107. doi:10.22146/jpsi.34966

Berntsen, D., \& Rubin, D. C. (2006). Emotion and vantage point in autobiographical memory. Cognition and Emotion, 20(8), 1193-1215. doi:10.1080/02699930500371190

Chang, J.-H., Huang, C.-L., \& Lin, Y.-C. (2012). The psychological displacement paradigm in diarywriting (pdpd) and its psychological benefits. Journal of Happiness Studies, 14(1), 155-167. doi:10.1007/s10902-012-9321-y

Cavanagh, S. (1997). Content analysis: concepts, methods and applications. Nurse Researcher, 4(3), 5-16. doi:10.7748/nr.4.3.5.s2

Cole, D. A., Maxwell, M. A., Dukewich, T. L., \& Yosick, R. (2010). Tergeted peer victimization and the construction of positive and negative selfcognitions: Connections to depressive symptoms in children. J Clin Child Adolesc Psychol, 39(3), 421-435. doi:10.1080/15374411003691776.

Dewey, J. (1933) How we think. Buffalo, New Y: Prometheus Books.

Danoff-burg, S. (2016). Stepping back to move forward: Expressive writing promotes self distancing. Emotion, 16(2), 349-364. doi: 10.1111/j.1467-9280.2005.01600.x

Elo, S., \& Kyngas, H. (2008). The qualitative content analysis. Journal of Advanced Nursing, 62(1), 107-115. doi:10.1111/j.13652648.2007.04569.x

Kross, E., Ayduk, O., \& Mischel, W. (2005). When asking "why" does not hurt distinguishing rumination from reflective processing of negative emotions. Psychological Science, 16(9), 709-715. doi:10.1111/j.14679280.2005.01600.x

Kross, E., \& Ayduk, O. (2008). Facilitating adaptive emotional analysis: Distinguishing distancedanalysis of depressive experiences from immersed-analysis and distraction. Personality and Social Psychology Bulletin, 34(7), 924-938. doi:10.1177/0146167208315938

Kross, E., Duckworth, A., Ayduk, O., Tsukayama, E., \& Mischel, W. (2011). The effect of selfdistancing on adaptive versus maladaptive self-reflection in children. Emotion, 11(5), 1032-1039. doi:10.1037/a0021787

Kross, E., Emma, B.-S., Park, J., Burson, A., Dougherty, A., Shablack, H.,Ayduk, O. (2014). Self-talk as a regulatory mechanism: How you do it matters. Journal of Personality and Social Psychology, 106(2), 304-324. doi:10.1037/a0035173

Feldner, M. T., Zvolensky, M. J., Eifert, G. H., \& Spira, A. P. (2003). Emotional avoidance: An experimental test of individual differences and response suppression using biological challenge. Behaviour Research and Therapy, 41 403-411. doi: 10.1016/S0005-7967(02)00020-7

Graybeal, A., Sexton, J. D., \& Pennebaker, J. W. (2002). The role of story-making in disclosure writing: the psychometrics of narrative. Psychology \& 
Health, 17(5), 571-581. doi: $10.1080 / 08870440290025786$.

Grossmann, I., \& Kross, E. (2014). Exploring Solomon's paradox: Self-distancing eliminates the self-other asymmetry in wise reasoning about close relationships in younger and older adults. Psychological Science, 25(8), 15711580. doi: $10.1177 / 0956797614535400$.

Holmes, \& Rahe. (1967). Holmes and Rahe Stress Scale. In Davis, M, Eshelman, E, and McKay, M (ed). The Relaxation and Stress Reduction Workbook. 1995, New Harbinger Productions, Inc.

Kelly, J.B., (2003) Childhood. SAGE Publications. London, Thousand Oaks and New Delhi,

Krippendorff, K. (1991). Analisis Isi: Pengantar teori dan Metodologi. (F. Wajidi, Ed.). Rajawali Press. Jakarta

Kross, E., \& Ayduk, O. (2017). Self-Distancing: Theory, Research, and Current Directions. In Advances in Experimental Social Psychology (p.81-136.). vol. 55. Elsevier Inc. doi: 10.1016/bs.aesp. 2016.10.002

Kross, E., \& Grossman, I. (2011). Boosting wisdom: distance from the self enhances wise reasoning, attitudes, and behavior. Journal of Experimental Psychology: General, 141(1), 4348. doi: $10.1037 / \mathrm{a} 0024158$

Lee.C.M. \& Bax, K.A (2000) Children's reactions to parental separation and divorce. Paediatr Child Health, 5(4) 217-218, doi: 10.1093/pch/5.4.217

Leersnyder, J. De, Boiger, M., \& Mesquita, B. (2015). Cultural differences in emotions. Emerging Trends: Culture and Emotion, 1-22. doi: 10.1002/9781118900772.etrds0060

Margola, D., Travagin, G., \& Dennis, J. L. (2018). Taking a step back: Self-distancing dynamics in adolescent writing about peer problems. Journal of Adolescence, 65, 6-15. doi: 10.1016/j.adolescence.2018.02.007

Mc.Isaac, H. K., \& Eich, E. (2004). Vantage Point in Traumatic Memory. Psychological Science, 15(4), 248-253. doi: 10.1111/j.09567976.2004.00660.x

Mischel, W., Shoda, Y., \& Rodriguez, M. L. (2014). Delay of gratification in children. Science, 224, 933-938. doi: 10.1126/science. 2658056

Mor, N., \& Winquist, J. (2002). Self-focused attention and negative affect: A meta-analysis. Psychological Bulletin, 128(4), 638-662. doi: 10.1037//0033-2909.128.4.638

Nazarian, D., \& Smyth, J. M. (2013). An experimental test of instructional manipulations in expressive writing interventions: Examining processes of change. Journal of Social and Clinical Psychology, 32(1), 71-96. doi: 10.1521/jscp.2013.32.1.71

Niles, A. N., Haltom, K. E., Mulvenna, C. M., Lieberman, M. D., \& Stanton, A. L. (2014). Randomized controlled trial of expressive writing for psychological and physical health: the moderating role of emotional expressivity. Anxiety, stress, and coping, 27(1), 1-17. doi: 10.1080/10615806.2013.802308

Nolen-Hoeksema, S., Wisco, B. E., \& Lyubomirsky, S. (2008). Rethinking rumination. Perspectives on Psychological Science, 3(5), 400-424. doi: 10.1111/j.1745-6924.2008.00088.x

Nugraheny. D. E, (2016, 7 Oktober). Kasus anak korban perceraian tinggi, Diunduh dari https://www.republika.co.id/berita/koran/h alaman-1/16/10/07/oeo5ft47-kasus-anakkorban-perceraian-tinggi

Pennebaker, J. W. (1997). Opening up: The healing power of expressing emotion. New York: Guilford Press.

Pennebaker, J. W., \& Chung, C. K. (2007). Expressive writing and its links to mental and physical health. In H. S. Friedman (Ed.). New York: Oxford University Press.

Pennebaker, J. W., \& Seagal, J. D. (1999). Forming a story: The health benefits of narrative. Journal of Clinical Psychology, 55, 1243-1254. doi: 10.1002/(sici)10974679(199910)55:10<124 3::aid-jclp6>3.0.co;2-n

Petitmengin, C. (2006). Describing one's subjective experience in the second person: An interview method for the science of consciousness. Phenomenology and the Cognitive Sciences, 5(34), 229-269. doi:10.1007/s11097-006-9022-2

Saunders, B., Sim, J., Kingstone, T., Baker, S., Waterfield, J., Bartlam, B., ... Jinks, C. (2017). Saturation in qualitative research: Exploring its conceptualization and operationalization. Quality \& Quantity, 52(4), 1893-1907. doi: 10.1007/s11135-017-0574-8

Silvia, B. P. J., Eichstaedt, J., \& Phillips, A. G. (2005). Are Rumination and reflection types of selffocused attention? Personality and Individual Differences, 38, 871-881. doi: 10.1016/j.paid.2004.06.011

Traue, H. C., Kessler, H., \& Deighton, R. M. (2016). Emotional Inhibition. Stress: Concepts, Cognition, Emotion, and Behavior, 233-240. doi: 10.1016/b978-0-12-800951-2.00028-5 